\title{
A survival predicting model for patients with papillary renal cell carcinoma
}

\author{
Boda Guo $^{1,2} \wedge$, Ming Liu ${ }^{1,2} \wedge$ \\ ${ }^{1}$ Department of Urology, Beijing Hospital, National Center of Gerontology, Institute of Geriatric Medicine, Chinese Academy of Medical Sciences, \\ Beijing, China; ${ }^{2}$ Graduate School of Peking Union Medical College, Beijing, China \\ Correspondence to: Ming Liu. Department of Urology, Beijing Hospital, National Center of Gerontology, Institute of Geriatric Medicine, Chinese \\ Academy of Medical Sciences, China. Email: liumingbjhu@126.com.
}

Submitted Jul 26, 2020. Accepted for publication Aug 28, 2020.

doi: $10.21037 /$ tau-20-1119

View this article at: http://dx.doi.org/10.21037/tau-20-1119

We commend the work of Yan et al. (1) for their retrospective study developing nomograms to predict the survival outcomes of patients with papillary renal cell carcinoma (pRCC), which may aid in clinical decisionmaking. As such, there are a few points that we would like to bring up.

The study included patients whose pRCC was the first tumor but did not exclude multiple primary cancers. However, another SEER-based study showed renal cell carcinoma (RCC) patients were at a significantly higher risk of developing a second malignancy, which may affect patients' survival (2).

RCC surgery in the SEER database includes cryosurgery, partial nephrectomy, and radical nephrectomy, etc. Previous studies have also proved that the prognosis of RCC patients with early $\mathrm{T}$ stage receiving different types of surgical treatment is different $(3,4)$. It would be more meaningful to stratify patients according to the type of surgery that they received; in this way, readers can easily see which surgical treatment improves pRCC patient's survival better.

Because there is lack of granularity in SEER about type of chemotherapy and only a small number of patients had received chemotherapy (3.25\%), the authors' finding that chemotherapy was a negative prognostic factor should be treated with reservation. Previous case reports showed pRCC patients with long-term cancer control by chemotherapy $(5,6)$.

The number of patients younger than 40 years old and older than or equal to 80 years old in their study is too small. Continuous variables, such as age, can be divided based on the optimal cut-off value generated by $\mathrm{X}$-tile software, making grouping more reasonable.

SEER database provides information of four metastatic sites (lung, liver, bone and brain), which could be considered for inclusion in their study. This is because considering whether patients had the above four sites of metastases rather than whether they were in M1 stage will improve predictive accuracy of their model to some extent.

\section{Acknowledgments}

Funding: None.

\section{Footnote}

Provenance and Peer Review: This article was a free submission to the journal. The article did not undergo external peer review.

Conflicts of Interest: All authors have completed the ICMJE uniform disclosure form (available at http://dx.doi. org/10.21037/tau-20-1119). The authors have no conflicts of interest to declare.

Ethical Statement: The authors are accountable for all aspects of the work in ensuring that questions related to the accuracy or integrity of any part of the work are appropriately investigated and resolved.

^ ORCID: Boda Guo, 0000-0001-8373-4584; Ming Liu, 0000-0001-9557-5488. 
Open Access Statement: This is an Open Access article distributed in accordance with the Creative Commons Attribution-NonCommercial-NoDerivs 4.0 International License (CC BY-NC-ND 4.0), which permits the noncommercial replication and distribution of the article with the strict proviso that no changes or edits are made and the original work is properly cited (including links to both the formal publication through the relevant DOI and the license). See: https://creativecommons.org/licenses/by-nc-nd/4.0/.

\section{References}

1. Yan $\mathrm{H}, \mathrm{Wei} \mathrm{X}, \mathrm{Wu} \mathrm{A}$, et al. Nomograms for predicting overall and cancer-specific survival in patients with papillary renal cell carcinoma: a population-based study using SEER database. Transl Androl Urol 2020;9:1146-58.

2. Chakraborty S, Tarantolo SR, Batra SK, et al. Incidence

Cite this article as: Guo B, Liu M. A survival predicting model for patients with papillary renal cell carcinoma. Transl Androl Urol 2020;9(5):2313-2314. doi:10.21037/tau-20-1119 and prognostic significance of second primary cancers in renal cell carcinoma. Am J Clin Oncol 2013;36:132-42.

3. Yang F, Zhou Q, Xing N. Comparison of survival and renal function between partial and radical laparoscopic nephrectomy for T1b renal cell carcinoma. J Cancer Res Clin Oncol 2020;146:261-72.

4. Pecoraro A, Palumbo C, Knipper S, et al. Cryoablation Predisposes to Higher Cancer Specific Mortality Relative to Partial Nephrectomy in Patients with Nonmetastatic pT1b Kidney Cancer. J Urol 2019;202:1120-6.

5. Liu $Z$, Chow MWL, Lua AHC, et al. Rare isolated synchronous splenic metastasis in a patient with type II papillary renal cell carcinoma. AME Case Rep 2018;2:9.

6. Zou XP, Jiang YY, Liao Y, et al. The coexistence of a Wilms' tumor and renal cell carcinoma in children: a case report and review of the literature. Onco Targets Ther 2019;12:953-8. 